\title{
Testing for the presence of a terrane boundary within Neoproterozoic (Dalradian) to Cambrian siliceous turbidites at Callander, Perthshire, Scotland
}

\author{
P. W. GEOFF TANNER ${ }^{1} \&$ MALCOLM S. PRINGLE ${ }^{2}$ \\ ${ }^{1}$ Division of Earth Sciences, Gregory Building, University of Glasgow, Glasgow G12 8QQ, UK \\ (e-mail: G.Tanner@earthsci.gla.ac.uk) \\ ${ }^{2}$ Isotope Geosciences Unit, Scottish Universities Environmental Research Centre, East Kilbride, Glasgow G75 0QF, UK
}

\begin{abstract}
The Southern Highland Group (Dalradian) and Keltie Water Grit Formation, which includes the Lower Cambrian Leny Limestone, form an inverted, $1.4 \mathrm{~km}$ thick, largely arenaceous, sequence at Callander. The grits have the same detrital mineralogy throughout, mainly quartz, plagioclase $\left(\mathrm{An}_{1-3}\right)$, muscovite, and biotite. Chlorite formed from detrital biotite during low-grade regional metamorphism $\left(T<270^{\circ} \mathrm{C}\right.$ ). There are some vertical changes in major element (but not trace element) chemistry of the grits, and detrital muscovites have a wide, but comparable, range in composition throughout, apart from an influx of Na-rich micas in the Keltie Water Grits. ${ }^{40} \mathrm{Ar} /{ }^{39} \mathrm{Ar}$ laser fusion dating of detrital muscovites yields an age spectrum with a peak at 1600-1800 Ma in the Dalradian rocks; similar old ages occur in the Keltie Water Grits but are diluted by ages of 507-886 Ma. We interpret these new data as showing that the rocks were most likely deposited as a single sequence, possibly with a disconformity, in Neoproterozoic to Early Cambrian times, before the onset of Grampian orogenesis in the Early Palaeozoic. No major structural or stratigraphical breaks have been identified and there is no direct evidence for the presence of two separate terranes.
\end{abstract}

Keywords: Dalradian, Cambrian, Grampian orogeny, ${ }^{40} \mathrm{Ar} /{ }^{39} \mathrm{Ar}$, detritus.

The Callander area (Fig. 1) is unique in being the only place where rocks belonging to the Scottish Dalradian Supergroup are considered to be in normal stratigraphical contact with fossiliferous strata of known (Cambrian) age (Harris 1962; Tanner 1995). However, this interpretation has been challenged by other workers who consider that part of the

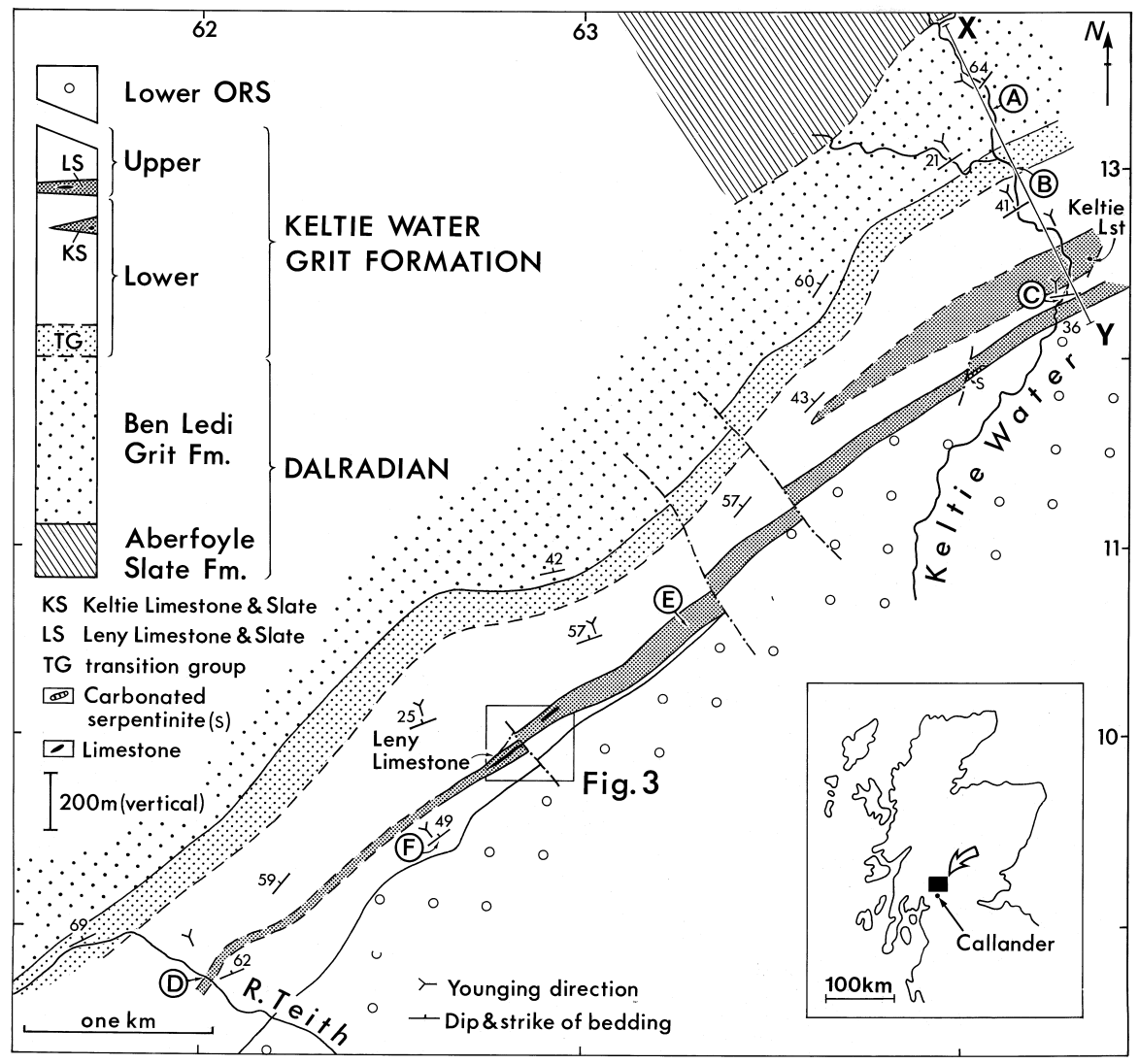

Fig. 1. Geological map of the Callander area showing the stratigraphical relationship between the Dalradian Supergroup and members of the Keltie Water Grit Formation. Localities A-F are mentioned in the text. XY, line of cross-section shown in Fig. 2; small inset shows the location of Fig. 3. Large inset shows the location of the Callander area in the Highland Border region of Scotland. 
Table 1. Stratigraphical sequence in the Callander area

Upper Keltie Water Grits

Leny Limestone \& Slate unit

Upper

Lower Keltie

Water Grits

(with local Keltie

Limestone \& Slate unit)

transition group

Ben Ledi Grit Fm.

DALRADIAN

succession belongs to the Highland Border Complex, and that a terrane boundary (Highland Boundary Fault) separates the sequence containing the fossiliferous Lower Cambrian Leny Limestone (Pringle 1939; Cowie et al. 1972), from the Dalradian rocks (Bluck et al. 1992; Brasier et al. 1992). In view of the current controversy over the age of the Dalradian Supergroup, and of the Grampian orogenic event which affects it (see Tanner \& Bluck, this volume), it is important to resolve this problem and determine whether there is an unbroken stratigraphical sequence, a disconformity, an angular unconformity, or a major tectonic break (fault or terrane boundary), between the Dalradian and Cambrian strata at Callander.

Previous work has shown that all of the pre-Devonian rocks at Callander were affected by the same sequence of structural events, and the structural fabrics in the 'Dalradian' and 'Cambrian' rocks have the same geometry (Stone 1957; Harris 1962; Harris \& Fettes 1972; Tanner 1995, 1998; Harris et al. 1998). This aspect will not be considered further here, except to point out that the above conclusion is possibly at variance with some radiometric data from elsewhere in the Dalradian block which indicate that at least part of the block may have been affected by pre-500 Ma deformation and metamorphism (Harper 1967; Dempster 1985; Dempster et al. 1995, 1997; Evans \& Soper 1997).

The aims of this work were to carry out a more detailed study of the stratigraphical succession at Callander than previously (Tanner 1995), and to obtain new information on the grits within this sequence, such as their whole-rock chemistry, detrital mineralogy and mineral chemistry, and ${ }^{40} \mathrm{Ar} /{ }^{39} \mathrm{Ar}$ ages on detrital white micas, which could be used to test for similarities and differences between the Dalradian and Cambrian parts of the sequence.

\section{Stratigraphy}

A new stratigraphical framework for the Callander area was proposed by Tanner (1995), who provided a detailed review of previous work. The distribution of the stratigraphical units (Table 1) and their relative thicknesses, are shown on Fig. 1. The entire sequence is inverted and youngs consistently to the south (Fig. 2) on the evidence of graded bedding, thin crosslaminated tops to some beds, and on centimetre- to decimetrescale, lobate bottom (?load) structures. Right-way up beds are restricted to the common limbs of mesoscopic folds of bedding (Fig. 2a-c).

\section{Dalradian}

These rocks are correlated with the Ben Ledi Grits (sensu stricto) found northwest of the outcrop of the Aberfoyle Slates (Harris 1962). They consist of green and grey-green grits in beds up to $1.5 \mathrm{~m}$ thick, interbedded with thin units of grey, green and purple slate.

\section{Keltie Water Grit Formation}

This formation is characterized by pale grey to white, siliceous grits with a carbonate-rich matrix, associated with black, graphitic slates with dolomitic layers and rare, locally fossiliferous, dark grey limestones. The boundary between the green Dalradian grits and the overlying pale grits of the Keltie Water Grit Formation is impossible to define precisely in the field (Clough in Geikie 1897, p. 28). As pale-coloured grits of Keltie Water-type occur well down into the underlying Dalradian sequence, i.e. at loc. A (Fig. 1) [NN 6415.1338], their presence cannot be used to define a boundary with the Keltie Water Grit Formation. In addition, the disappearance upwards in the sequence of green chloritic grits has no particular stratigraphical significance as this is a metamorphic feature, chlorite in the grits having been derived from the breakdown of detrital biotite.

Transition group. An arbitrary upper limit to the Dalradian Ben Ledi Grits is placed at the uppermost chlorite-pink feldspar-bearing grit recognized in the field and a 'transition group' containing both green and pale coloured grits is found between the Dalradian and Keltie Water Grits. This is best seen at loc. B (Fig. 1) [NN 6425.1302] where interbedded grey-green grits and slates with a 'Dalradian' aspect pass southwards into a mixed group of dark green and pale grits, with green and purple slates. These rocks are succeeded to the southeast by grey and white siliceous grits, with some grey slates.

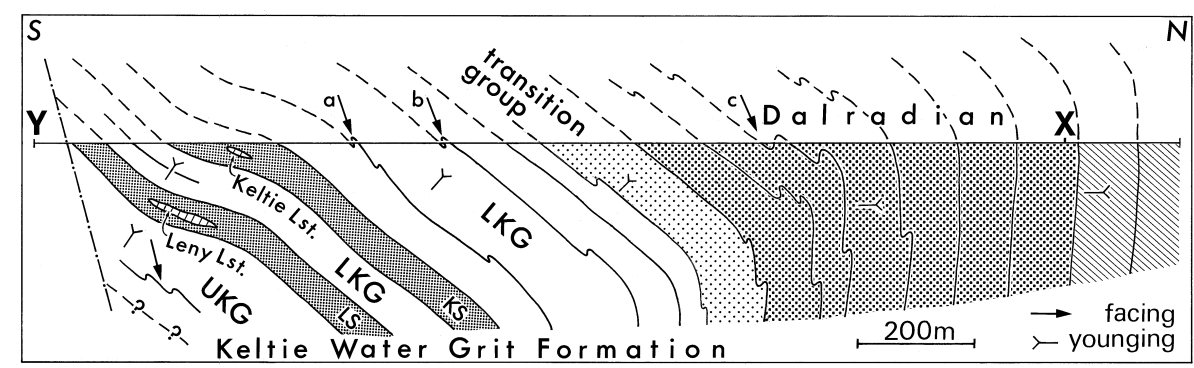

Fig. 2. True scale cross-section showing the relationship between the Dalradian rocks (Ben Ledi Grit Fm., heavy stipple; Aberfoyle Slate Fm., cross-hatched) and members of the inverted Keltie Water Grit Formation. The latter consists of (from the base upwards): transition group; Lower Keltie Water Grits (LKG), which includes the Keltie Limestone and Slate unit (KS); Leny Limestone and Slate unit (LS); and Upper Keltie Water Grits (UKG). The line of section (XY) is shown on Fig. 1. Localities a, b and c are referred to in the text. 
Lower Keltie Water Grits. In the Keltie Water this member consists of two sequences of pale-coloured grits (the Lower and Upper Leny Grits of Harris $(1962,1970))$, separated by the Keltie Limestone and Slate unit. The lower part consists mainly of thickly bedded (up to $>3 \mathrm{~m}$ ) white or grey grits which seldom develop argillaceous tops.

The Keltie Limestone \& Slate unit consists of grey slates overlain by black graphitic slates, and thence by grey and variegated slates (for details, see Tanner 1995, fig. 3). The grey, pale-weathering, banded slate at the base contains a bed several metres thick of orangeweathering, finely laminated dolomite. This slate is in fault contact with a thick unit of black, graphitic slates which contain numerous bands of pale grey, laminated dolomitic slate and dolomite, and rare thin, dark bands of limestone and chert, and are cut by veins of orange-weathering carbonate, and quartz. Staining and qualitative SEM analysis of several samples of dolomite shows that it is a Mn-rich, ferroan dolomite $\left(\mathrm{Ca}_{0.52} \mathrm{Mg}_{0.29} \mathrm{Fe}_{0.12} \mathrm{Mn}_{0.7}\right) \mathrm{CO}_{3}$, which is cut by millimetre-thick veins of similar composition. At their southern margin, the black slates interdigitate with, or are interfolded with, pale grey and variegated slates, and contain one thick unit of dolomite (sampled, without success, for microfossils; S. Sutherland pers. comm). These rocks are followed by a $30 \mathrm{~m}$ wide outcrop of grey slates with dolomitic lenses.

In a disused working $100 \mathrm{~m}$ up the left bank tributary of the Keltie Water (the Allt na Mna Ruaidhe) at [NN 6468.1252], a lens-shaped body of the Keltie Limestone (Fig. 1) occurs in black slate. It is a grey calcite limestone cut by numerous, randomly orientated calcite veins; dissolution of a limestone sample in HF yielded much organic material but no recognisable chitinozoa or other microfossils (S. Sutherland pers. comm).

The upper part of this member, as seen in the Keltie Water at loc. C (Fig. 1), consists of white or pale-coloured, brown-weathering, grits in beds up to $60 \mathrm{~cm}$ thick, with a few metres of purple and ochre slates.

Leny Limestone and Slate Member. There is an asymmetry within this member: purple and grey slates are overlain stratigraphically by a thick unit of black graphitic slate in Leny quarry (where it includes limestones), the Keltie Water, and the River Teith. This sequence is completely unlike that found in the Keltie Limestone and Slate unit, with which it was previously correlated (Harris 1962).

Limestone is only found in the area of Leny Quarry. Two separate limestones were quarried, the main limestone and a thinner packet of limestones enclosed in black slates to the southeast, as is clearly shown on the cross-section drawn by Nicol (1863, fig. 4). The main limestone (Fig. 3, loc. 1) was a grey, calcite-veined body which, according to reports in the $1860 \mathrm{~s}$, varied in thickness from $1.5-8 \mathrm{~m}$ (for review, see Rushton et al. in press). In 1896, Clough (unpublished data) reported that the remaining exposure of this limestone varied laterally in thickness from 0.3 to $1.5 \mathrm{~m}$ over a distance of some $7 \mathrm{~m}$; it is no longer exposed.

Southeast of the main limestone, six, thin, dark limestone bands up to $10 \mathrm{~cm}$ thick in a total thickness of $30 \mathrm{~cm}$, comprise the 'Leny Limestone'; they occur in a thick unit of dull black, pyritous slate exposed on the SE wall at loc. 2 (Fig. 3). It was from this locality that a trilobite fauna of upper Lower Cambrian age was reported (Pringle 1939; Cowie et al. 1972). The black slates locally contain thin bands of orange-weathering dolomite and a breccia horizon. Staining, SEM, and XRF analysis show that the Leny Limestone generally consists of a mosaic of calcite crystals $\left(\left(\mathrm{Ca}_{0.99} \mathrm{Mg}_{0.01} \mathrm{Fe}_{<0.003} \mathrm{Mn}_{<0.003}\right) \mathrm{CO}_{3}\right.$ with scattered crystals of zoned, euhedral dolomite, graphite, quartz, feldspar, and pyrite. It is cut by several generations of calcite-dolomite veins and is virtually indistinguishable in appearance, petrography, and chemistry from the Keltie Limestone. The Leny and Keltie limestones are similar in composition (analyses can be obtained from the Society Library or the British Library Document Supply Centre, Boston Spa, Wetherby, West Yorkshire LS23 7BQ, UK as Supplementary Publication No. SUP18138 (16 pages)) to the purer of the limestones in the Appin Group, such as the Dufftown Limestone in NE Scotland (Thomas 1989, table 2). Dissolution of samples of the Leny Limestone in HF did not yield any recognizable chitinozoa (Sutherland pers. comm.).

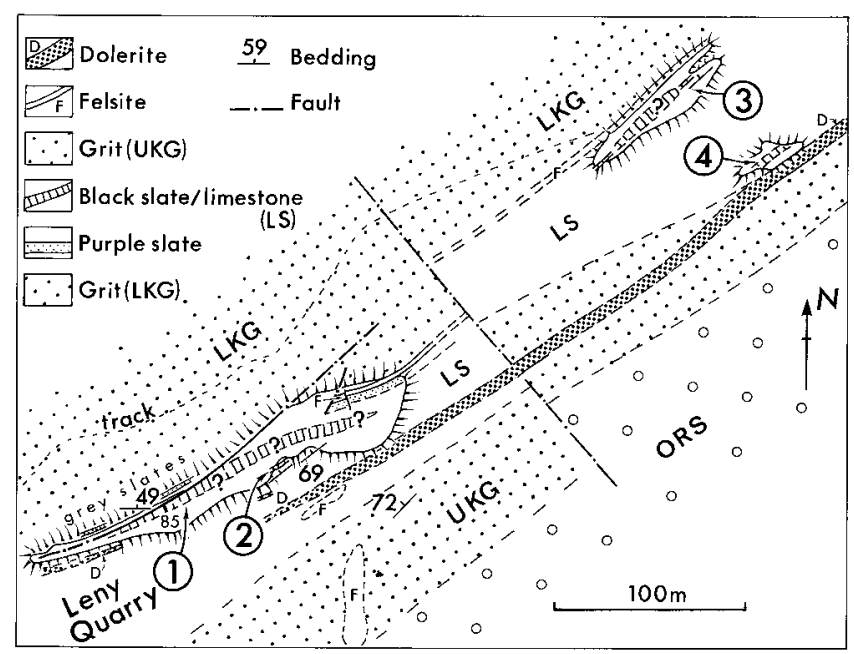

Fig. 3. Geological map of Leny quarry, and of two smaller workings to the north-east, showing the inferred locations of the main quarried limestone (1, $3 \& 4$ ), and of the Leny Limestone (2) (see text for further details). The Lower Keltie Water Grit Formation (LKG) is succeeded southwards by the inverted Leny Limestone and Slate Fm. (LS), and by the Upper Keltie Water Grit Formation (UKG). Open circles, Lower Old Red Sandstone lavas and sediments. Dip and strike of bedding are shown; faults are shown as bold, pecked lines.

For much of its length the NW face of the quarry is bounded by a fault surface which dips to the southeast at $85^{\circ}$ (Fig. 3). This fault is not thought to have caused any major displacement of the Leny Limestone and Slate unit, as the same overall sequence of lithologies from north to south is found in Leny quarry, the Keltie Water and other sections: it is a late, brittle structure causing a small local offsetting of the outcrop (Figs $1 \& 3$ ), and not a terranebounding discontinuity (Read 1961; Bluck et al. 1992; Brasier et al. 1992).

Of the two other workings, a small exposure of limestone and black slate is still to be found in the northern one (Fig. 3, loc. 3), which exposed a $5 \mathrm{~m}$ thick limestone unit in 1865 (Nicol 1863); that to the southeast (loc. 4) is now a barren pit bounded on the south side by a dolerite dyke, but once exposed a thin limestone band (Clough 1896). The interpretation of the Leny quarry area given here agrees with those of Anderson (1947, fig. 8) and Harris (1969).

In the Keltie Water, a poorly exposed $60 \mathrm{~m}$ section across this unit consists mainly of slates, intruded by two dolerite dykes (15 and $0.6 \mathrm{~m}$ thick) and small, irregular bodies of grey quartz-feldspar porphyry. No way-up structures were noted. Most of the stratigraphically lower part of the section $(26 \mathrm{~m})$ is in purple- and ochre-coloured slates; these are overlain by units of dark grey siltstone, grey slates with sandstonesiltstone ribs, and then by black slates, some with orange-weathering carbonate lenses.

At loc. D (Fig. 1) [NN 6009.0870], intermittent exposures of purple slate ( $40 \mathrm{~m}$ across) are followed stratigraphically (southeastwards) by grey slate which grades over a distance of $6 \mathrm{~m}$ into black slate with chert bands which makes up the $\mathrm{N}$ wall of the quarry. Purple siltstones with thin grit bands in the $\mathrm{S}$ wall are followed by $c .60 \mathrm{~m}$ of massive grit. At loc. E [NN 1062.6254], the Leny Limestone member is seen as strongly sheared, dull grey slates containing thin bands of chert, and quartz veins.

Upper Keltie Water Grits. This unit is best exposed in Leny Burn (loc. F, Fig. 1) [NN 6122.0948] and along the side of the A.84 between loc. $\mathrm{D}$ and the ORS outcrop; it also crops out south of Leny Quarry. The member consists mainly of pale grits, with clasts to $3 \mathrm{~mm}$ in diameter, and includes a few thin bands of purple slate and siltstone. 
Table 2. Summary of the petrography of the grits from the Callander area

\begin{tabular}{|c|c|c|c|c|c|c|c|c|c|c|}
\hline & $\begin{array}{c}\text { Sample } \\
\text { no. }\end{array}$ & Colour & $\begin{array}{l}\text { Kaolinite } \\
\text { clasts }\end{array}$ & $\begin{array}{l}\text { Sericite-chlorite } \\
\text { matrix }\end{array}$ & $\begin{array}{c}\text { Sericite-carbonate } \\
\text { matrix }\end{array}$ & $\begin{array}{c}\text { Cloudy pink } \\
\text { albite }\end{array}$ & $\begin{array}{c}\text { Clear } / \text { sericitized } \\
\text { albite }\end{array}$ & $\begin{array}{l}\text { Clastic } \\
\text { biotite }\end{array}$ & Chlorite & Comments \\
\hline \multicolumn{11}{|l|}{$U K G$} \\
\hline & 240 & $\mathrm{~g}$ & & & $\mathrm{x}$ & $\square$ & - & & & \\
\hline & 241 & $\mathrm{~g}$ & & & $\mathrm{x}$ & $\square$ & - & & & \\
\hline & 157 & $\mathrm{~g}$ & $\mathrm{x}$ & & $\mathrm{x}$ & $\square$ & - & & & \\
\hline & 115 & $\mathrm{~g}$ & & & $\mathrm{x}$ & & $\bullet$ & & & CS \\
\hline & 161 & g & & & $\mathrm{x}$ & & - & & & \\
\hline & 245 & $\mathrm{~g}$ & & & $\mathrm{x}$ & $\square$ & $\bullet$ & & $\mathrm{x}, \mathrm{B}$ & \\
\hline \multicolumn{11}{|l|}{ Upper $L K G$} \\
\hline \multirow[t]{11}{*}{$\mathrm{AM}$} & $273^{*}$ & $\mathrm{~g}$ & $\mathrm{x}$ & & $\mathrm{x}$ & $\square$ & - & & & $\mathrm{An}_{1}$ \\
\hline & 282 & $\mathrm{~g}$ & $\mathrm{x}$ & & $\mathrm{x}$ & & & $\mathrm{x}, \mathrm{a}$ & & \\
\hline & 281 & $\mathrm{~g}$ & $\mathrm{x}$ & & $\mathrm{x}$ & & 0 & & & \\
\hline & 22 & $\mathrm{~g}$ & & & $\mathrm{x}$ & & 0 & & & $\mathrm{CS}$ \\
\hline & 72 & $\mathrm{~g}$ & & & $\mathrm{x}$ & & 0 & & & \\
\hline & $274 *$ & $\mathrm{~g}$ & & & $\mathrm{x}$ & & 0 & & & \\
\hline & 20 & $\mathrm{~g}$ & & & $\mathrm{x}$ & & & & & CS \\
\hline & 19 & $\mathrm{~g}$ & & & $\mathrm{x}$ & & & & & CS \\
\hline & $275^{*}$ & $\mathrm{~g}$ & $\mathrm{x}$ & & $\mathrm{x}$ & & & & & CS \\
\hline & 94 & w & & & $\mathrm{C}$ & & & & & \\
\hline & 95 & $\mathrm{~g}$ & $\mathrm{x}$ & & $\mathrm{x}$ & & & $\mathrm{t}$ & & \\
\hline \multicolumn{11}{|l|}{ Lower $L K G$} \\
\hline & 96 & $\mathrm{~W}$ & $\mathrm{x}$ & & $\mathrm{x}$ & & & & & CS \\
\hline & $291 *$ & $\mathrm{~g}$ & & & $\mathrm{x}$ & & 0 & $\mathrm{x}$ & & \\
\hline \multirow[t]{6}{*}{$\mathrm{AM}$} & $293^{*}$ & $\mathrm{~g}$ & $\mathrm{x}$ & & $\mathrm{x}$ & & 0 & $\mathrm{x}, \mathrm{a}$ & & \\
\hline & 137 & $\mathrm{~g}$ & $\mathrm{x}$ & & $\mathrm{x}$ & & & $\mathrm{x}$ & & \\
\hline & 67 & W & & & $\mathrm{C}$ & & & & & CS \\
\hline & 66 & g & $\mathrm{x}$ & & $\mathrm{x}$ & & & $\mathrm{x}, \mathrm{a}$ & & \\
\hline & 65 & g & $\mathrm{x}$ & & $\mathrm{x}$ & & 0 & $\mathrm{x}, \mathrm{a}$ & & \\
\hline & 9 & $\mathrm{~g}$ & $\mathrm{x}$ & & $\mathrm{x}$ & & & & & \\
\hline \multirow[t]{10}{*}{ M } & $294 *$ & $\mathrm{~g}$ & & & $\mathrm{x}$ & & 0 & & & $\mathrm{An}_{1}$ \\
\hline & 8 & $\mathrm{~g}$ & & & $\mathrm{C}$ & & & & & \\
\hline & 63 & $\mathrm{~g}$ & & $\mathrm{x}$ & & $\mathrm{x}$ & 0 & & $\mathrm{x}, \mathrm{B}$ & \\
\hline & $239^{*}$ & gr-gn & & & $\mathrm{x}$ & & 0 & & & \\
\hline & 64 & $\mathrm{w}$ & & & $\mathrm{x}$ & & 0 & & & CS \\
\hline & $238^{*}$ & $\mathrm{gr}$ & $\mathrm{x}$ & & $\mathrm{x}$ & & 0 & & $\mathrm{x}, \mathrm{B}$ & \\
\hline & 62 & & & $\mathrm{x}$ & & $\mathrm{x}$ & 0 & & $\mathrm{x}, \mathrm{B}$ & \\
\hline & 362 & & & $\mathrm{x}$ & & $\mathrm{x}$ & 0 & & $\mathrm{x}, \mathrm{B}$ & \\
\hline & 61 & $\mathrm{~g}$ & $\mathrm{x}$ & & $\mathrm{x}$ & & & & & \\
\hline & $227^{*}$ & $\mathrm{~g}$ & $\mathrm{x}$ & & $\mathrm{x}$ & & & & & \\
\hline \multicolumn{11}{|l|}{ Trans } \\
\hline & 59 & $\mathrm{~g}$ & $\mathrm{x}$ & & $\mathrm{x}$ & & 0 & & & \\
\hline & 60 & g & & & $\mathrm{x}, \mathrm{c}$ & & - & & $\mathrm{x}, \mathrm{B}$ & \\
\hline & $230^{*}$ & $\mathrm{~g}$ & $\mathrm{x}$ & & $\mathrm{x}, \mathrm{c}$ & & $\bullet$ & & $\mathrm{x}, \mathrm{B}$ & \\
\hline & $229^{*}$ & $\mathrm{~g}$ & $\mathrm{x}$ & & $\mathrm{x}, \mathrm{c}$ & & 0 & $\mathrm{t}$ & $\mathrm{x}, \mathrm{B}$ & \\
\hline & 361 & gn & & $\mathrm{x}$ & & & 0 & $\mathrm{t}$ & $\mathrm{x}, \mathrm{B}$ & \\
\hline & 360 & $\mathrm{~g}$ & $\mathrm{x}$ & & $\mathrm{x}, \mathrm{c}$ & & - & $\mathrm{x}$ & $\mathrm{x}$ & \\
\hline & $225^{*}$ & gn & & & $\mathrm{x}, \mathrm{c}$ & & - & $\mathrm{x}, \mathrm{a}$ & $\mathrm{x}$ & \\
\hline $\mathrm{AM}$ & $232 *$ & $\mathrm{~g}$ & $\mathrm{x}$ & & $\mathrm{x}$ & & - & $\mathrm{x}$ & & \\
\hline \multicolumn{11}{|l|}{ Dalradian } \\
\hline & $224^{*}$ & gr-gn & & $\mathrm{x}$ & & $\square$ & - & $\mathrm{x}$ & $\mathrm{x}, \mathrm{B}$ & \\
\hline & 58 & gn & & $\mathrm{x}$ & & $\square$ & - & & $\mathrm{x}, \mathrm{B}$ & \\
\hline & $223^{*}$ & gn & & $\mathrm{x}$ & & घ & - & $\mathrm{x}$ & $\mathrm{x}, \mathrm{B}$ & \\
\hline $\mathrm{AM}$ & $222 *$ & $\mathrm{gr}$ & & & $\mathrm{x}$ & $\overline{\mathbf{a}}$ & $\bullet$ & & & $\mathrm{An}_{1-3}$ \\
\hline \multirow[t]{6}{*}{ M } & $221^{*}$ & gn & & & $\mathrm{x}$ & च & - & & $\mathrm{x}, \mathrm{B}$ & $\mathrm{An}_{1-3}$ \\
\hline & 53 & gn & & $\mathrm{x}$ & & a & $\bullet$ & $\mathrm{t}$ & $\mathrm{x}, \mathrm{B}$ & \\
\hline & $220^{*}$ & gn & & $\mathrm{x}$ & & 口 & $\bullet$ & & $\mathrm{x}$ & \\
\hline & $219^{*}$ & gn & $\mathrm{x}$ & & $\mathrm{x}$ & & & & $\mathrm{x}$ & \\
\hline & 324 & gn & & $\mathrm{x}$ & & ש & • & & $\mathrm{x}, \mathrm{B}$ & \\
\hline & $218^{*}$ & gn & $\mathrm{x}$ & & $\mathrm{x}$ & & & $\mathrm{x}$ & & \\
\hline \multirow[t]{8}{*}{$\mathrm{AM}$} & $368^{*}$ & gn & $\mathrm{x}$ & & $\mathrm{x}$ & & & $\mathrm{x}, \mathrm{a}$ & & \\
\hline & 57 & gn & $\mathrm{x}$ & & $\mathrm{x}$ & & & & & \\
\hline & 56 & gn & $\mathrm{x}$ & & $\mathrm{x}$ & & & $\mathrm{x}$ & & \\
\hline & 55 & gn & $\mathrm{x}$ & & $\mathrm{x}$ & & & $\mathrm{x}$ & & \\
\hline & 356 & gn & $\mathrm{x}$ & & $\mathrm{x}$ & $\square$ & - & & $\mathrm{x}, \mathrm{B}$ & \\
\hline & 325 & gn & $\mathrm{x}$ & & $\mathrm{x}$ & 口 & - & $\mathrm{x}$ & $\mathrm{x}, \mathrm{B}$ & \\
\hline & 357 & $\mathrm{gr}$ & & $\mathrm{x}$ & & च & - & $\mathrm{x}$ & $\mathrm{x}, \mathrm{B}$ & \\
\hline & 358 & gn & $\mathrm{x}$ & & $\mathrm{x}$ & a & $\bullet$ & $\mathrm{x}, \mathrm{a}$ & & \\
\hline
\end{tabular}


Table 2. Continued

\begin{tabular}{|c|c|c|c|c|c|c|c|c|c|}
\hline $\begin{array}{l}\text { Sample } \\
\text { no. }\end{array}$ & Colour & $\begin{array}{l}\text { Kaolinite } \\
\text { clasts }\end{array}$ & $\begin{array}{l}\text { Sericite-chlorite } \\
\text { matrix }\end{array}$ & $\begin{array}{c}\text { Sericite-carbonate } \\
\text { matrix }\end{array}$ & $\begin{array}{l}\text { Cloudy pink } \\
\text { albite }\end{array}$ & $\begin{array}{l}\text { Clear/sericitized } \\
\text { albite }\end{array}$ & $\begin{array}{l}\text { Clastic } \\
\text { biotite }\end{array}$ & Chlorite & Comments \\
\hline \multicolumn{10}{|l|}{ Dalradian continued } \\
\hline 359 & gn & & $\mathrm{x}$ & & च & - & & $\mathrm{x}, \mathrm{B}$ & \\
\hline 326 & gn & & $\mathrm{x}$ & & a & - & & & \\
\hline $216^{*}$ & gn & & $\mathrm{x}$ & & च & - & $\mathrm{x}$ & $\mathrm{x}, \mathrm{B}$ & \\
\hline $215^{*}$ & gn & & $\mathrm{x}$ & & घ & - & & $\mathrm{x}, \mathrm{b}$ & \\
\hline $214^{*}$ & gn & $\mathrm{x}$ & $\mathrm{x}$ & & $\overline{\mathbf{a}}$ & - & $\mathrm{x}$ & $\mathrm{x}, \mathrm{B}$ & \\
\hline 54 & gn & & $\mathrm{x}$ & & च & - & $\mathrm{x}$ & $\mathrm{x}, \mathrm{B}$ & \\
\hline $213^{*}$ & gn & & $\mathrm{x}$ & & घ & - & $\mathrm{x}, \mathrm{a}$ & $\mathrm{x}, \mathrm{B}$ & \\
\hline $212 *$ & gn & & $\mathrm{x}$ & & घ & - & $\mathrm{x}, \mathrm{a}$ & $\mathrm{x}, \mathrm{B}$ & \\
\hline $211^{*}$ & gn & & $\mathrm{x}$ & & च & - & & $\mathrm{x}, \mathrm{B}$ & \\
\hline
\end{tabular}

x, present; A, Ar-Ar dating; M, microprobe analysis; *XRF analysis; a, altered; B, chlorite-white mica stacks after bi; c, minor chlorite; C, carbonate-only matrix; CS, clast-supported grit; $t$, rare.

Colour of grits: w, white; g, pale grey; gr, dark grey; gr-gn, grey-green; gn, green.

$\square \bigcirc$, Small clasts (pink and clear/sericitized albite, respectively).

—, Large clasts (pink and clear/sericitized albite, respectively).

LKG, Lower Keltie Water Grits; UKG, Upper Keltie Water Grits; Trans, transition group. All sample numbers have the prefix 'KW'.

In summary, the Keltie Water Grits young consistently southwards; stratigraphical units can be traced laterally and show a consistent internal asymmetry; and there is no evidence that major faults have disrupted this pattern.

\section{Petrography}

This study is based upon the examination of over 100 thin sections of coarse-grained, arenaceous rocks from the Keltie Water, and the valley of the River Teith (Fig. 1). Although all of the samples are referred to here as 'grits', only $46 \%$ of them contain grains $>2 \mathrm{~mm}$ across (with $21 \%>3 \mathrm{~mm}$ ) and can be properly classified as such, the majority being of coarse to very coarse sandstone.

\section{Clast composition}

The 'grits' are poorly sorted and consist of sub-rounded to sub-angular clasts of quartz, with variable proportions of feldspar, and lesser amounts of lithic fragments, set in a finer grained matrix. Most samples are matrix-supported (with uncommon clast-supported grits appearing up-sequence) and show a striking similarity in overall texture throughout the sequence. The matrix comprises ubiquitous detrital muscovite, sometimes with biotite, and differing proportions of sericite, carbonate and chlorite, with minor zircon, tourmaline and opaque crystals, and rare rutile grains.

The quartz clasts are mainly single crystals, some having a pale blue opalescence in hand specimen. The latter contain orientated sets of fine needles (1-2 $\mu \mathrm{m}$ across and $>100 \mu \mathrm{m}$ long) which were found by SEM and electron microprobe analysis to consist of rutile or tantalo-rutile, with some (?) ilmenite.

Feldspar occurs either as clear to slightly sericitized crystals, or as brownish, 'dusty' crystals which appear pink in hand specimen, and are a characteristic feature of the Southern Highland Group. Microprobe analysis of a number of these crystals from different levels within the sequence (Table 2 ) shows that they are invariably of nearly pure albite $\left(\mathrm{An}_{1-3}\right)$ and do not show compositional or obvious textural zoning.

The largest and most clearly defined lithic clasts are dark-coloured 'rip-up' clasts of calcareous mudrock, and of chlorite aggregates rich in opaque minerals; they are generally several times larger than the other fragments, and similar in lithology to the slates found from the same sequence. Other clasts include (?) quartzite and rare clasts of recrystallized quartz mylonite. Igneous clasts include aggregates of irregularly-shaped quartz-albite crystals $(0.1-0.4 \mathrm{~mm}$ across); crystals of feldspar preserving embayments occupied by the original finegrained igneous matrix; mosaics of fine-grained $(<0.2 \mathrm{~mm})$ albite; and rare clasts consisting of a few large quartz and albite grains. Fresh, commonly euhedral, crystals of biotite, rutile, tourmaline, and zircon occur within some of the large quartz clasts.

A distinctive clast type $(0.5-1.0 \mathrm{~mm}$ across) found in many of the grits (Table 2) consists of a mosaic of minute $(10-50 \mu \mathrm{m})$ platelets of kaolinite, commonly associated with, or rimmed by, $\mathrm{Mg}$-Fe-carbonate. Identification of the kaolinite was confirmed by XRD and microprobe analysis. One detrital clast consists of an albite crystal, two-thirds of which is altered to this type of mosaic, suggesting that the kaolinite formed from the breakdown of plagioclase.

Detrital muscovite crystals, commonly bent around neighbouring clasts of quartz and feldspar, are ubiquitous and reach $0.3-0.5 \mathrm{~mm}$ in length. Detrital biotite crystals (up to $0.4 \mathrm{~mm}$ long in thin section) are common in a number of samples; although retaining their brown-olive pleochroism (?indicative of an igneous origin) they are rarely fresh, have diffuse outlines in thin section, and show very low $\mathrm{K}$ contents. The sequence of alteration of biotite laths to partially retrogressed biotites with white mica and chlorite, to discrete green chlorite-white mica stacks (Table 2, 'B') is seen in many thin sections. In others the process is complete and only the chlorite-mica stacks are seen.

In Dalradian feldspathic grits, the matrix is usually of sericite and chlorite (Table 2). Staining shows that carbonate is very rare, and usually occurs only as small calcite crystals occupying cracks in quartz and feldspar clasts. In the Keltie Water Grits, the matrix is partly to almost entirely, of a darker, Fe- and Mg-rich (sideritic) carbonate.

\section{Vertical variations in clast type}

The stratigraphical distribution of the various types of grit and the nature of their clasts and matrix (Table 2), taken together with the spatial distribution of detrital biotite and cloudy, pink albites, clearly demonstrates that there is a fairly continuous gradation in mineralogy, clast type etc., from the Dalradian rocks to the top of the Keltie Water Grit Formation. The question is: which of these features are of primary (detrital) origin, and which have resulted from post-depositional diagenesis and alteration caused by fluid flux through the turbidite pile subsequent to its deposition? 
The main petrographical features shown by all grits in this c. $1.4 \mathrm{~km}$ thick sequence are: (1) they have very similar rounding, sorting, and clast : matrix characteristics; (2) the range in types of quartz- and albite-bearing mineral and lithic clasts is the same; (3) kaolinite-bearing clasts, with $\mathrm{Mg}-\mathrm{Fe}$-rich carbonate, are found in pale grits at all levels; (4) detrital feldspar is albite throughout $\left(\mathrm{An}_{1-3}\right)$; (5) detrital muscovite, blue (rutilated) quartz, zircon, opaque grains, and tourmaline occur in every grit that has been sectioned.

The changes in the grits that occur upwards are: (6) they become progressively more siliceous and less feldspathic upwards: non-feldspathic and pale grits increase in number, and clast-supported quartz grits appear for the first time (Table 2, 'CS'); (7) the matrix changes from sericite-chlorite to sericite-carbonate, with the latter becoming more $\mathrm{Fe}$ - and Mg-rich upwards; (8) large clasts of cloudy albite (pink in hand specimen) are common in the lower part of the sequence, absent in the middle, but reappear in rocks at the very top of the sequence; (9) clear to slightly sericitized albites decrease in amount upwards, are only seen in the matrix of a few samples in the Lower Keltie Water Grits, but become a major constituent again in the Upper Grits; and, (10) there is a decline upwards in the amount of detrital biotite, and of chlorite-muscovite stacks formed from them.

Features (1) (2) (5) (6) (8-10) are of primary, detrital origin, as may be (7), whereas the presence of kaolinite (3) and albite (4) are wholly or partly due to burial diagenesis. The mode of origin of the albite will be discussed elsewhere.

\section{Discussion}

The grade of metamorphism is low throughout the sequence with no evidence that the Dalradian rocks ever attained a higher metamorphic grade than those of the Keltie Water Grit Formation, or had been affected by a separate, earlier, metamorphic event. The preservation of detrital biotite at all stratigraphical levels (albeit mainly unstable and commonly partially altered to chlorite), and the incomplete development of chlorite-muscovite stacks from biotite, indicate that the temperature probably did not exceed $270^{\circ} \mathrm{C}$ (Jiang \& Peacor 1994). Chlorite is mainly, if not wholly, secondary after biotite, but some may have formed from clay and Fe-ore in the matrix. The only previously published report of detrital biotite from the Highland Border Dalradian is by Jehu \& Campbell (1917, p. 200) from the Aberfoyle area 10-20 km SW of Callander.

The provenance region for the entire turbidite sequence had a very clearly defined mineralogy: quartz, feldspar, muscovite, biotite, zircon, tourmaline, kaolinite and opaque minerals. The lithic clasts are too small $(<5 \mathrm{~mm})$ to indicate the precise nature of the coarse-grained host rocks which were the primary source for most of the clastic material, but some show textures typical of quartz porphyry and aplite, and others have textures similar to those found in quartz veins, mylonitic shear zones, and sedimentary quartzite. There is an overall lack of metamorphic detritus, and with the above exceptions, most of the clasts appear to be of igneous derivation.

\section{Analytical methods}

Care was taken to ensure that all of the analysed material was free from weathering, which in the case of some of the Keltie Water Grits meant removing a $10-15 \mathrm{~cm}$ thick, brown weathered crust prior to sampling the pale grey or white interior of the bed.
Major and trace element analysis of 28 whole rock samples of limestone and grit was carried out on a Phillips 1450 at Glasgow by $\mathrm{X}$-ray fluorescence spectrometry (XRF) after techniques referred to in Leake (1996).

Detrital muscovite, albite and kaolinite were analysed from polished sections using a Camebax SX-50 microprobe with four mass spectrometers, operated with an accelerating voltage of $15 \mathrm{kV}$, sample current of $6 \mathrm{nA}$, using a beam $<5 \mu \mathrm{m}$ in diameter. Fe is calculated as $\mathrm{FeO}$, and white mica formulae are calculated on a basis of $24[\mathrm{O}, \mathrm{OH}]$.

White micas for ${ }^{40} \mathrm{Ar} /{ }^{39} \mathrm{Ar}$ dating were hand-picked from a crushed, sieved, and washed $0.2-0.5 \mathrm{~mm}$ size fraction, loaded into Al foil packets, sealed in a $10 \mathrm{~mm}$ i.d. quartz vial, and irradiated for $120 \mathrm{~h}$ in the CLICIT facility of the 1MW Oregon State University (USA) TRIGA reactor. Reactor corrections for the CLICIT facility, as determined by analyses of optical grade $\mathrm{CaF}_{2}$ and degassed Fedoped K-rich glass from both this and previous irradiations, are $\left({ }^{40} \mathrm{Ar} /{ }^{39} \mathrm{Ar}\right) \mathrm{K}=0.00086,\left({ }^{39} \mathrm{Ar} /{ }^{37} \mathrm{Ar}\right) \mathrm{Ca}=0.000264$, and $\left({ }^{39} \mathrm{Ar} /{ }^{37} \mathrm{Ar}\right)$ $\mathrm{Ca}=0.000673$. The irradiation flux parameter, $J$, was monitored relative to packets of the $97.9 \mathrm{Ma}$ ANU standard biotite GA1550 loaded at least every $10 \mathrm{~mm}$ among the unknown minerals, and is known to better than $0.3 \%$ at any given position in the vial. Single white mica and standard biotite crystals were loaded into $2 \mathrm{~mm}$ wide, $3 \mathrm{~mm}$ deep wells in a 259-hole $\mathrm{Cu}$ sample planchett, placed in a c. $400 \mathrm{cc}$ ultra high vacuum extraction line, and heated overnight with a heat lamp to about $150^{\circ} \mathrm{C}$. Argon was extracted by melting the crystals for $20-30 \mathrm{~s}$ with a $10-30 \mathrm{~W}$, multi-mode CW Nd-YAG laser beam defocused to about $500 \mu \mathrm{m}$ in diameter. The released gas was cleaned for $3 \mathrm{~min}$ with a $50 \mathrm{l} / \mathrm{s}$ SAES $\mathrm{Zr} / \mathrm{Al}$ getter heated to $400^{\circ} \mathrm{C}$, followed by a second stage where it was also exposed to a second $50 \mathrm{l} / \mathrm{s}$ SAES $\mathrm{Zr} / \mathrm{Al}$ getter held at room temperature. The cleaned gas was analysed in static mode with a MAP 215 rare gas mass spectrometer with an adjustable slit set at a nominal resolution of about 600 and an EMI multiplier operated at a gain of about $5000 .{ }^{40} \mathrm{Ar} /{ }^{39} \mathrm{Ar}$ age and error calculations include terms for the error in the blank and reactor corrections. The total system blank was measured every 4-6 analyses, was dominated by the mass spectrometer background $(>90 \%)$, and did not change during the course of individual experiments. Thus, a daily or even several-day running average was used for the age calculations; typical blanks were less than $2 \times 10^{-16} \mathrm{~mol}^{40} \mathrm{Ar}, 2 \times 10^{-18} \mathrm{~mol}{ }^{39} \mathrm{Ar}$, and $8 \times 10^{-17} \mathrm{~mol}{ }^{38} \mathrm{Ar},{ }^{37} \mathrm{Ar}$, and ${ }^{36} \mathrm{Ar}$. All errors are reported as the standard deviation of analytical precision.

\section{Whole-rock geochemistry}

Twenty-six samples of grit from the Keltie Water section were analysed by XRF. The samples were taken at fairly regular intervals over $1.7 \mathrm{~km}$ of stream section from the lowest level of the Dalradian Ben Ledi Grits to the top of the Lower Keltie Water Grit. A sample location map and major and trace element whole-rock (XRF) analyses are available as a Supplementary Publication (see p. 1207).

\section{Results}

The green, grey-green, and pale grits which comprise most of the sequence show relatively small variations in composition, and reflect the variable dilution of other constituents by detrital quartz. Mean values for both major and trace elements of grits from the Dalradian sequence (11 samples) and Keltie Water Grit Formation (10 samples) are similar (XRF analyses are available as a Supplementary Publication (see p. 1207), apart from $\mathrm{Na}_{2} \mathrm{O}$, which differs significantly $(2.28 \%$ and $0.52 \%$, respectively) and reflects the relative scarcity of albite in the Keltie Water Grit Formation. MgO is lower in the Keltie Water Grits, and these rocks also contain more carbonate. An uncommon type of pale, matrix-supported calcareous grit with $>5 \% \mathrm{CO}_{2}$ occurs in all three units but has a rather variable 


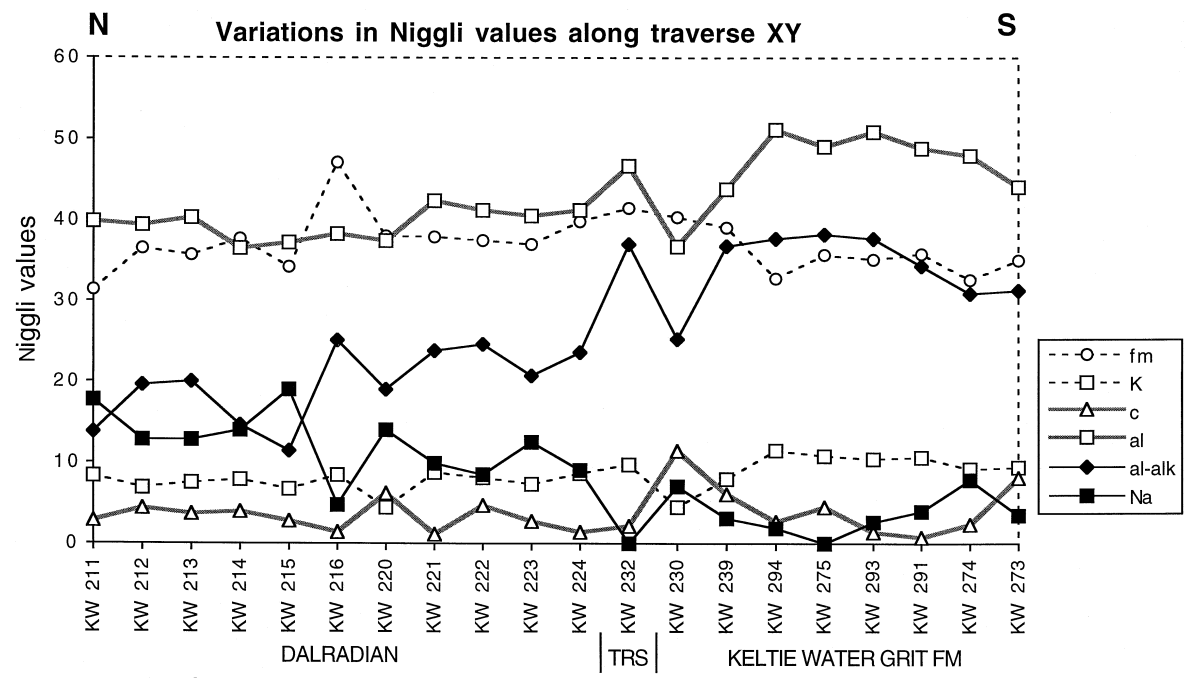

Fig. 4. Diagram showing Niggli values for grits from the Dalradian, transition group (TRS), and Keltie Water Grit Formation (KWGF) from the Keltie Water, near Callander, plotted against stratigraphical position along the Keltie Water traverse (XY on Fig. 1). The samples are shown in their correct relative positions, but the $\mathrm{X}$-axis spacing is not drawn to scale. Niggli $N a$ and $K$ are values for elements calculated in exactly the same way as Niggli numbers. composition, and these samples (analyses are available as a Supplementary Publication (see p. 1207)) were not included on Fig. 4.

Trace elements do not show much variation between samples. When plotted on discrimination diagrams (i.e. Bhatia \& Crook 1986), the Dalradian grits form tight clusters which, in the case of the La-Th diagram overlap with those defined by the transition group and Keltie Water Grit Formation. The latter units generally show higher $\mathrm{Zr}$ values than the Dalradian rocks and form a linear array on the La-Th plot, which lies to the high $\mathrm{Zr}$, low Th side of the Dalradian field. The consistently low values for $\mathrm{Cr}$ and $\mathrm{Ni}$ indicate that neither ophiolitic nor ultramafic rocks contributed debris to the basin before the Lower Cambrian.

In order to examine the chemical variations between grit samples, and avoid the masking effect of variable $\mathrm{SiO}_{2}$ dilution, the data were plotted on the Niggli $m g$ v. al-alk and $f m \mathrm{v}$. al-alk diagrams (see van de Kamp \& Leake 1985 and Leake 1996, for the application of Niggli diagrams to clastic sediments). On these plots (which are available as a Supplementary Publication, see p. 1207), the samples from the Dalradian grits and the Keltie Water Grits define separate fields, as determined by their relative contents of clastic biotite (fresh, or altered to chlorite) and albite. The maximum separation between the two groups is shown on the al-alk against $\mathrm{fm}$ plot: the difference is a consequence of higher $\mathrm{Na}$ values in the Dalradian rocks than in the Keltie Water Grits, and lower Al values (due to lesser amounts of sericite in the matrix compared with the other grits).

Finally, in order to examine the spatial variations in wholerock chemistry, certain Niggli parameters are plotted against geographical location, and hence stratigraphical position, in Fig. 4. Some Niggli values such as $f m$ and $c$ do not show much variation; $K$ increases slightly up-sequence; and $m g$ declines slightly. However, as would be anticipated from the above discussion, $a l$ and al-alk rise considerably in value upsequence, and $\mathrm{Na}$ falls, with the change occurring at about the boundary between the Dalradian rocks and the Keltie Water Grit Formation. From the available data it is not clear whether this change in composition is abrupt or transitional in nature. When plotted in a similar fashion, trace element concentrations (in $\mathrm{ppm}$ ) do not show any noticeable variation with stratigraphical level.
In conclusion, there is a difference in whole-rock geochemistry between the Dalradian grits and Keltie Water Grits that could have arisen from a progressive change in the nature of the source terrain with time. However, the rather abrupt changes in some Niggli parameters at the level of the transition group could be interpreted as indicating the presence of a local disconformity, and an even more profound break in sequence is not excluded by the whole rock chemistry. However, no samples were analysed from the Upper Keltie Water Grits, in which detrital albite reappears (Table 2), so there is probably not a clear division in overall chemistry between the Dalradian grits and Keltie Water Grits.

\section{Detrital white micas: chemistry and ${ }^{40} \mathrm{Ar} /{ }^{39} \mathrm{Ar}$ ages}

Detrital white mica is found in all of the grits, ranges in maximum length from 0.2 to $0.5 \mathrm{~mm}$, and consists of thin plates with a high length : width ratio. As the largest and most abundant mica flakes are found in the pale grits, which have a sericite-carbonate matrix (Table 2), these rocks were chosen for microprobe and $\mathrm{Ar}-\mathrm{Ar}$ study.

\section{White mica chemistry}

The detrital white micas from seven samples (Dalradian, 3; transition group, 1; Keltie Water Grit Formation, 3) were analysed by electron microprobe to test whether the mica populations show any change in chemistry with stratigraphical level, as might be expected if more than one distinctive source terrain were supplying detritus to the sedimentary basin, or basins. No sample from the Upper Keltie Water Grits was analysed. The micas are fresh but as they show some variation in composition from core to rim only the compositions of the centres of the grains were used here. 19-23 grains/sample were analysed in this preliminary study and representative individual analyses of micas from across the compositional range are available as a Supplementary Publication, see p. 1207.

\section{Results}

The data were plotted on geochemical diagrams to show the main variations in white mica chemistry. In the $\mathrm{Si}-100 \mathrm{Mg}$ / 


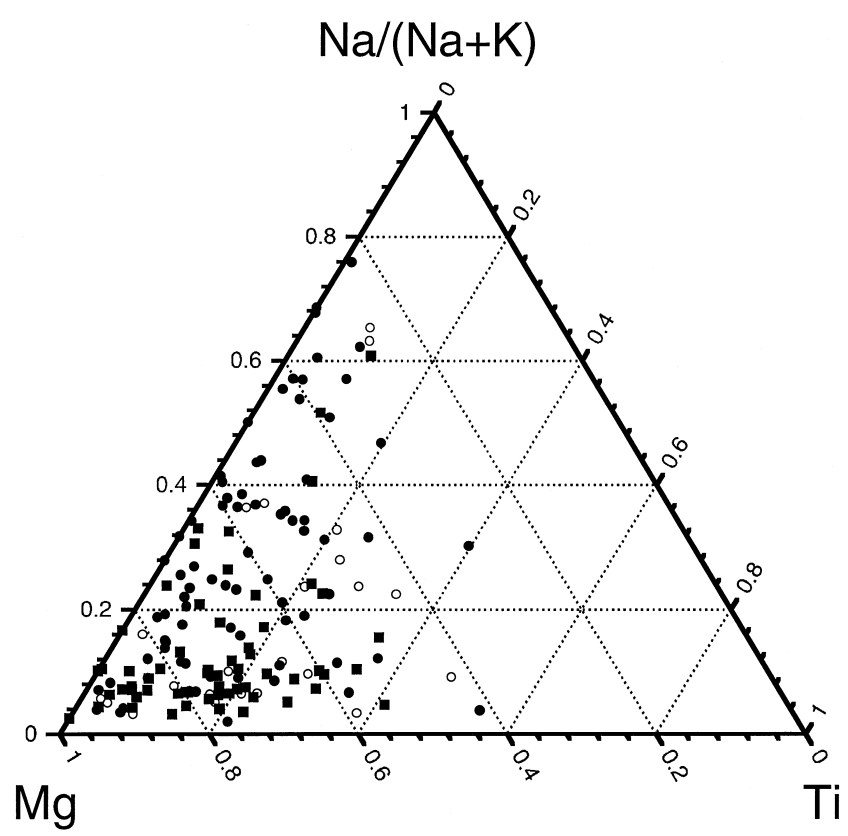

Fig. 5. Analyses of detrital white micas from grits belonging to the Dalradian (solid squares), and transition group (open circles), and Keltie Water Grit Formation (solid circles) from the Keltie Water, near Callander, plotted on a $\mathrm{Mg}-\mathrm{Ti}-\mathrm{Na} /(\mathrm{Na}+\mathrm{K})$ diagram. All elements are in cations per formula unit.

$(\mathrm{Mg}+\mathrm{Fe}+\mathrm{Mn})$ diagram (available as a Supplementary Publication, see p. 1207) the data show a wide range in composition: the white micas vary from Si-poor to Si-rich, and show large variations in $\mathrm{Mg} /(\mathrm{Mg}+\mathrm{Fe}+\mathrm{Mn})$ ratios. However, it is important to record that the compositional ranges for the Dalradian and Keltie Water Grit Formation are virtually indistinguishable. As the greatest difference between individual micas is in their $\mathrm{Na}$ content, $\mathrm{Si}$ was plotted against $\mathrm{Na}$ / $(\mathrm{Na}+\mathrm{K})$ (available as a Supplementary Publication, see p. 1207). This diagram shows that, for a given $\mathrm{Si}$ value, micas from the Keltie Water Grit Formation are generally more Na-rich, with the micas in the transition group having intermediate or 'Dalradian' values.

As the petrography of the grits indicates that some of the detritus was derived from an acid igneous terrain, the mica analyses were plotted on an Fe-Ti-Mg diagram (available as a Supplementary Publication, see p. 1207) (Speer 1984, and references therein). This diagram shows that most of the white micas have a low $\mathrm{Ti}$ content (igneous micas generally have higher Ti contents) but that there is a very close similarity in their $\mathrm{Ti}, \mathrm{Fe}$ and $\mathrm{Mg}$ contents regardless of stratigraphical position.

On the $\mathrm{Mg}-\mathrm{Ti}-\mathrm{Na} /(\mathrm{Na}+\mathrm{K})$ diagram (Fig. 5) a higher proportion of white micas from the Keltie Water Grit Formation have a $\mathrm{Na} /(\mathrm{Na}+\mathrm{K})$ ratio $>0.2$, than do the Dalradian micas, with those from the transition group occurring across the compositional range of the other two types.

These results show that although the detrital white micas were probably derived from a wide variety of rock types and/or geological environments, the ranges in $\mathrm{Si}, \mathrm{Mg}, \mathrm{Fe}$, and $\mathrm{Ti}$ contents are similar for the Dalradian, transition group, and Keltie Water Grit Formation. Although the influx of Na-rich micas in the Keltie Water Grit Formation suggests that there may have been a change in the nature of the source area with stratigraphical level, it is important to note that detrital micas of this composition are also found within the Dalradian and transition group rocks (Fig. 5).

\section{${ }^{40} \mathrm{Ar} /{ }^{39} \mathrm{Ar}$ dating of detrital micas}

${ }^{40} \mathrm{Ar} /{ }^{39} \mathrm{Ar}$ ages on detrital muscovites record the time at which the host rocks cooled below $c .350^{\circ} \mathrm{C}$ during their exhumation (i.e. McDougall \& Harrison 1988), and thus provide a useful indicator of sedimentary provenance. In particular, they may provide a temporal link between sedimentation, and the rate and timing of exhumation in the source area (i.e. Copeland \& Harrison 1990; Kelley \& Bluck 1992; Turner et al. 1996).

Five samples of pale siliceous grit with a carbonate-sericite matrix, and containing detrital white micas up to $0.5 \mathrm{~mm}$ in diameter, were selected for this study: two from the Dalradian sequence (KW 222 \& 368); one from the transition group (KW 232); and two from the Keltie Water Grits (KW 273 \& 293). Sample locations are available as a Supplementary Publication, see p. 1207, and the petrography in Table 2. Up to 14 individual white micas were hand-picked from each sample and analysed by single crystal $\mathrm{Ar}-\mathrm{Ar}$ laser fusion techniques.

\section{Results}

The results are listed in Table 3 and summarized in Fig. 6. All of the micas are $>600 \mathrm{Ma}$ old, with the exception of one grain from the transition group (KW 232, Table 3) which has an apparent age of $507 \pm 5 \mathrm{Ma}$. The host sediment is slightly older than Lower Cambrian in age (509-517 Ma; Davidek et al. 1998) and this grain is either unique in the Keltie Water data set in having the same age as the sediment, or has been affected by diagenetic alteration, to give an anomalously young age.

Laser-fusion analysis shows a wide range in $\mathrm{K} / \mathrm{Ca}$ ratios for the white micas (Table 3 ). Whereas $\mathrm{K} / \mathrm{Ca}$ ratio is not a very sensitive indicator of alteration in white micas, low $\mathrm{K} / \mathrm{Ca}$ (less than perhaps 20) is suggestive of significant diagenetic alteration. We note that three of the 61 individual micas analysed have $\mathrm{K} / \mathrm{Ca}$ ratios $<20$, and that these crystals have among the youngest apparent ages in their respective populations. Microprobe spot analysis shows that, as expected, $\mathrm{Ca}$ is below the detection limit in most white micas, with only 9 out of 134 determinations giving values $>0.009$ cations/formula unit.

The ${ }^{40} \mathrm{Ar} /{ }^{39} \mathrm{Ar}$ data show that none of the mica ages has been reset to Caledonian (Palaeozoic) ages by the lowgrade regional metamorphism(s) that has affected the whole sequence. In the Lower Keltie Water Grits which lie immediately below the fossiliferous Lower Cambrian rocks (c. 509$517 \mathrm{Ma}$ old), the micas are all older than $646 \mathrm{Ma}$, whereas the oldest detrital ages (up to $2271 \mathrm{Ma}$ ) come from the more deeply buried, Dalradian, rocks.

The age spectra (Fig. 6) show that there is a progressive change in age pattern upwards in the stratigraphical sequence. At the base, there is a tight cluster of ages ranging from 1260-1760 Ma in the Dalradian rocks (Fig. 6a), with a peak of 1500-1700 Ma, and one older age (2271 Ma). The overlying transition group (Fig. 6b) shows features intermediate between those of the other two groups, with a poorly-defined maximum at 1400-1700 Ma, two older ages of $2100 \mathrm{Ma}$ (albeit 100$150 \mathrm{Ma}$ younger than that from the Dalradian), and a few micas with younger ages. In the two samples from the Keltie Water Grit Formation at the top of the sequence, the older, 1200-1700 Ma micas are well represented (Fig. 6c), again with one age of $2100 \mathrm{Ma}$, but are diluted by a significant influx of 
Table 3. ${ }^{40} \mathrm{Ar}{ }^{39} \mathrm{Ar}$ ages ( $\mathrm{Ma}$ ) of detrital white micas from pale grits in the Callander area

\begin{tabular}{|c|c|c|c|c|c|c|c|c|c|}
\hline \multicolumn{4}{|c|}{ Dalradian } & \multirow{2}{*}{\multicolumn{2}{|c|}{$\begin{array}{c}\text { Transition } \\
\text { KW } 232\end{array}$}} & \multicolumn{4}{|c|}{ Keltie Water Grit Formation } \\
\hline \multicolumn{2}{|c|}{ KW 368} & \multicolumn{2}{|c|}{ KW 222} & & & \multicolumn{2}{|c|}{ KW 293} & \multicolumn{2}{|c|}{ KW 273} \\
\hline Age \pm s.d. & $\mathrm{K} / \mathrm{Ca}$ & Age \pm s.d. & $\mathrm{K} / \mathrm{Ca}$ & Age \pm s.d. & $\mathrm{K} / \mathrm{Ca}$ & Age \pm s.d. & $\mathrm{K} / \mathrm{Ca}$ & Age \pm s.d. & $\mathrm{K} / \mathrm{Ca}$ \\
\hline $1730 \pm 4$ & 143 & $2271 \pm 5$ & 613 & $2144 \pm 10$ & 105 & $2146 \pm 7$ & 144 & $1624 \pm 6$ & 244 \\
\hline $1676 \pm 4$ & 85 & $1762 \pm 4$ & 878 & $2114 \pm 5$ & 109 & $1613 \pm 4$ & 158 & $1614 \pm 6$ & 312 \\
\hline $1661 \pm 4$ & 203 & $1642 \pm 4$ & 204 & $1659 \pm 8$ & 59 & $1461 \pm 2$ & 250 & $1565 \pm 4$ & 90 \\
\hline $1655 \pm 4$ & 50 & $1637 \pm 4$ & 107 & $1653 \pm 10$ & 112 & $1441 \pm 5$ & 121 & $1416 \pm 8$ & 38 \\
\hline $1627 \pm 4$ & 244 & $1637 \pm 4$ & 143 & $1606 \pm 4$ & 329 & $1191 \pm 5$ & 70 & $1365 \pm 5$ & 45 \\
\hline $1627 \pm 4$ & 461 & $1620 \pm 4$ & 189 & $1591 \pm 19$ & 14 & $1166 \pm 5$ & 374 & $1258 \pm 10$ & 25 \\
\hline $1593 \pm 4$ & 546 & $1609 \pm 4$ & 469 & $1539 \pm 7$ & 185 & $767 \pm 6$ & 329 & $1088 \pm 6$ & 213 \\
\hline $1587 \pm 4$ & 331 & $1546 \pm 4$ & 253 & $1467 \pm 4$ & 393 & $748 \pm 5$ & 109 & $886 \pm 3$ & 196 \\
\hline $1564 \pm 4$ & 183 & $1533 \pm 2$ & 1818 & $1467 \pm 18$ & 70 & $743 \pm 3$ & 69 & $863 \pm 5$ & 291 \\
\hline $1524 \pm 6$ & 1848 & $1515 \pm 4$ & 71 & $1298 \pm 9$ & 73 & $712 \pm 6$ & 63 & $646 \pm 3$ & 44 \\
\hline $1519 \pm 4$ & 74 & $1513 \pm 4$ & 111 & $867 \pm 10$ & 44 & $680 \pm 5$ & 190 & & \\
\hline $1416 \pm 5$ & 22 & $1387 \pm 4$ & 904 & $783 \pm 5$ & 320 & $675 \pm 15$ & 14 & & \\
\hline \multirow[t]{2}{*}{$1260 \pm 4$} & 215 & & & $683 \pm 9$ & 75 & & & & \\
\hline & & & & $507 \pm 5$ & 14 & & & & \\
\hline
\end{tabular}

The complete ${ }^{40} \mathrm{Ar} /{ }^{39} \mathrm{Ar}$ single-crystal total fusion data set is availabe as a Supplementary Publication, see p. 1207.

younger micas aged from 646-1088 Ma. Thus from the transition group upwards there is an influx of micas $<1200 \mathrm{Ma}$ old but the two samples from the Keltie Water Grit Formation still contain $50-60 \%$ of older micas from within the range shown by the Dalradian rocks.

In general, detrital white micas in a stratigraphical succession should show progressively younger ${ }^{40} \mathrm{Ar} /{ }^{39} \mathrm{Ar}$ ages

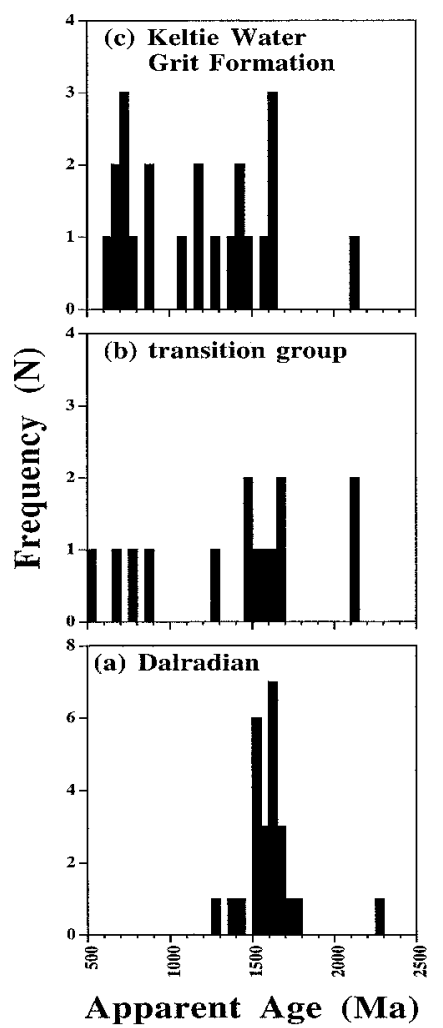

Fig. 6. ${ }^{40} \mathrm{Ar} /{ }^{39} \mathrm{Ar}$ laser fusion age spectra for detrital white micas from grits belonging to the Dalradian Supergroup, transition group, and Keltie Water Grit Formation from the Keltie Water, near Callander. up-sequence, as the upper $10 \mathrm{~km}$ of crust in the source area is removed to expose rocks which cooled through $350^{\circ} \mathrm{C}$ at later times. Indeed, where the source area is undergoing rapid uplift, the ${ }^{40} \mathrm{Ar} /{ }^{39} \mathrm{Ar}$ age of the detrital white micas is the same as the age of the sediment in which they are found (i.e. Copeland \& Harrison 1990; Turner et al. 1996). This is clearly not the case in the Keltie Water where the Dalradian to Cambrian sequence was laid down at some time after $595 \mathrm{Ma}$ (Halliday et al. 1989), and most of the detrital white micas are significantly older than this.

The Dalradian rocks appear to have been derived from a Mesoproterozoic, largely igneous, source region, and the presence of old micas with the same age range in the Keltie Water Grit Formation could be explained in one of two ways. Either the same source remained active, or the old micas were derived from a reworking of the Dalradian sediments during the establishment of a localised disconformity (? within the transition group) in late Neoproterozoic-Cambrian time. In either case, the old micas have been diluted by input of younger detritus, possibly from a new source, and two or more separate source areas could therefore have been involved. However, there is no indication from these data that the Keltie Water Grit Formation was derived from an entirely different source than the underlying Dalradian sequence. On balance, we consider that the age spectra can be most readily explained in terms of the deposition of a single sequence of rocks, albeit containing a possible disconformity, as opposed to two sequences which were laid down in geographically separate sedimentary basins differing in age by $>100 \mathrm{Ma}$, and juxtaposed subsequently by terrane amalgamation (Brasier et al. 1992).

There are no previously published ages on detrital micas from the Dalradian, but Pidgeon \& Compston (1992) recognized three populations of inherited zircons from the Ben Vuirich and Glen Kyllachy granites in the Dalradian block at 2750, 1700, and 950-1100 Ma. Rb-Sr ages of c. $1800 \mathrm{Ma}$ were reported by Dempster \& Bluck (1989) from white micas in cobbles of metasedimentary rock from a conglomerate in the Highland Border Complex at Aberfoyle. In addition, $\mathrm{Nd}$ model ages of $c$. 2000 Ma have been obtained by Fitches et al. 
(1996) from clasts in the Portaskaig Boulder Bed at the base of the Dalradian Argyll Group, with one clast giving a $\mathrm{Rb}-\mathrm{Sr}$ whole-rock -white mica age of $1570 \mathrm{Ma}$. The model ages are comparable with those reported from the Rhinns Complex (Fitches et al. 1996, and references therein), which may have formed part of the basement to the Dalradian. Although these ages are significantly older than the $c$. 1500-1700 Ma peak age reported here from the Dalradian rocks (Fig. 6a), and may not relate to the same event, or the same source, the age difference is consistent with the general observation that mica ages are younger than those of zircons from the same source area. There is no evidence of detrital micas of Grenville (c. $1000 \mathrm{Ma}$ ) age at Callander, and the $650-900 \mathrm{Ma}$ ages could represent magmatic, hydrothermal, or other events, which occurred prior to the earliest phase of Vendian rifting (c. $650 \mathrm{Ma})$. They may even include detritus derived from a crystalline Moine basement affected by the $800-850$ Ma Knoydartian event.

\section{Summary and discussion}

The new field data reported here strengthen the conclusion from previous work that the Dalradian Supergroup and the overlying pale grits and black slates of the Keltie Water Grit Formation form an essentially unbroken stratigraphical succession (Harris 1962; Tanner 1995), but the interpretation of some of the petrographical, geochemical, and ${ }^{40} \mathrm{Ar} /{ }^{39} \mathrm{Ar}$ results is less certain.

All of the grits at Callander, from the Dalradian rocks to the top of the Upper Keltie Water Grits, are of turbidite facies and have a very similar field appearance. The only obvious differences between them are in their colour and weathering characteristics, hence in their petrography. Petrographically and geochemically identical limestones are found at two different levels in the succession, the upper one being the fossiliferous Leny Limestone.

The grits making up the bulk of this $c .1 .4 \mathrm{~km}$ thick sequence have a distinctive detrital mineralogy throughout of quartz, feldspar, white mica, biotite, tourmaline and zircon. $\mathrm{K}$-feldspar is absent, and the amounts of detrital plagioclase and biotite decrease upwards. The typical green colour of the Dalradian grits in this section derives from the presence of chlorite after biotite and it is inferred that most of the chlorite in the Southern Highland grits formed in this manner. Identification of the pink feldspar clasts as nearly pure albite, rather than K-feldspar as is commonly thought to be the case for the large pink feldspar clasts in the Southern Highland Group, means that all earlier reports of K-feldspar from these rocks should be reassessed. These siliciclastic turbidites have a consistent detrital mineralogy throughout, but this has been strongly overprinted by the effects of burial diagenesis, which has almost certainly altered all of detrital plagioclase to nearly pure albite $\left(\mathrm{An}_{1-3}\right)$, and caused dissolution of any pre-existing $\mathrm{K}$-feldspar. The simplest interpretation of these data is that a single sequence showing some original vertical changes in lithology, especially in amounts of detrital plagioclase, was affected by diagenetic albitisation prior to being subjected to two or more deformational events and low grade regional metamorphism.

Analysis of the whole-rock geochemistry of the grits on Niggli diagrams shows that there are geochemical similarities and differences between grits at the base and top of the sequence. It is not possible to decide whether these differences reflect changes in the source material supplied to a single basin over time, result from variations in grain size and clay content, or could be taken as evidence that two sequences with similar chemistry have been tectonically juxtaposed. There is no geochemical evidence that the Highland Border ophiolite had been obducted and exposed to erosion by Early Cambrian time. The whole-rock analyses confirm the conclusion reached from the petrography that the main vertical changes in composition reflect a progressive upward decline in amounts of detrital plagioclase and biotite (or secondary chlorite derived from biotite).

Microprobe analysis of detrital white micas shows that they have a comparable range in $\mathrm{Si}, \mathrm{Fe}, \mathrm{Mg}$ and $\mathrm{Ti}$ contents at all levels of the sequence, with more sodic micas occurring in the transition group and younger rocks. The wide range in chemistry suggests that they were derived from a complex source region. ${ }^{40} \mathrm{Ar} /{ }^{39} \mathrm{Ar}$ laser fusion ages on white micas from the pale grits show that none of the mica ages has been reset by Caledonian regional metamorphism, agreeing with the results of the petrographical work that the regional metamorphism was of low greenschist facies throughout, with no detectable metamorphic breaks, and maximum temperatures probably not exceeding $270^{\circ} \mathrm{C}$. The age spectra show a gradation from all old mica ages in the Dalradian rocks (mainly 1600$1800 \mathrm{Ma}$, with a few at $2100 \mathrm{Ma}$ ) to a mixed population of old and younger white micas (507-886 Ma) in the transition group and Keltie Water Grit Formation. The influx of Na-rich micas may be responsible for the younger ages, but there are no means of cross-correlating between these two existing sets of data. Thus there are both similarities and differences in the composition and age spectra of the detrital white micas up-section which are consistent with either changes in provenance during the deposition of a single succession or, less convincingly, of the juxtaposition of two entirely separate, but similar, successions.

The most positive finding from this investigation is that there is no consistent suggestion from either the field observations or the various analytical data, of any discontinuity or sharp break at the same level within the sequence that might be taken to indicate the presence of a terrane boundary rather than a progressive change in the provenance of the sediments with time. There is also no evidence from the sedimentary structures that any major change in water depth took place within the sequence: an outer shelf edge environment for the grits would be consistent with that suggested for the Leny Limestone (Conway Morris \& Rushton 1988).

The interpretation proposed here is that the vertical lithological changes seen from the Dalradian to the top of the Keltie Water Grit Formation represent the establishment of a stable shelf environment, with the incoming of black muds, dark limestones, and dolostones, and an increase in the amount of (?)detrital carbonate in the turbidites. This finding does not sit well with the model that the Lower Cambrian rocks at Callander were deposited in an entirely separate, and much younger, sedimentary basin than the Dalradian rocks, and were part of an exotic terrane (Highland Border Complex) which docked with the latter sometime in the Devonian (Bluck 1990). In this hypothesis, the terrane boundary would be located somewhere within the transition group, which appears to be a normal stratigraphical member of the sequence and not to have arisen from a tectonic interleaving of quite disparate sedimentary sequences.

Confirmation of the original findings of Clough (in Geikie 1897) and Harris (1962), that there is no identifiable break between the Dalradian and the younger rocks, means that 
the upper part of the Dalradian succession (Southern Highland Group) must have been deposited between $646 \mathrm{Ma}$ (the youngest reliable detrital white mica age in the Keltie Water sequence (Table 3)) and c. 509-517 Ma, the probable age range of trilobite-bearing upper Lower Cambrian rocks (Davidek et al. 1998) such as the Leny Limestone. This conclusion is compatible with the $\mathrm{U}-\mathrm{Pb}$ age on zircon of $595 \pm 4$ Ma (Halliday et al. 1989) for the Tayvallich Volcanics which lie at the base of the Southern Highland Group, and with the $590 \pm 2 \mathrm{Ma}$ age for the Ben Vuirich Granite (Rogers et al. 1989), which hornfelsed the Dalradian rocks prior to the Grampian orogeny (Tanner \& Leslie 1994; Tanner 1996).

If an arbitrary allowance of at least $20 \mathrm{Ma}$ is made for the time taken for the tectonic thickening, metamorphism, and subsequent cooling of the high-level part of the Dalradian sequence preserved in the Highland Border zone, then all radiometric ages older than $480 \mathrm{Ma}$ from these rocks would be in serious conflict with the hypothesis presented here, that the top of the Southern Highland sequence is as young as 509 Ma. Both Harper (1967) and Dempster (1985) have published ages older than this from the Highland Border zone, and they require explanation.

Harper (1967) presented nine whole-rock K-Ar determinations on slates from the southernmost part of this zone which gave ages of 481-508 Ma. As the present study has shown that the ${ }^{40} \mathrm{Ar} /{ }^{39} \mathrm{Ar}$ ages of detrital white micas in these rocks were not reset during the metamorphism responsible for the formation of the slates, and as the latter can be shown to contain appreciable amounts of detrital white mica, then the rocks would be expected to yield anomalously old ages. Harper (1967, p. 59) recognised this potential problem, but assumed that all of the 'detrital Ar' had been lost during the cleavage-forming event.

As part of a study of uplift patterns along a transect across the Southern Highland rocks in Perthshire, Dempster (1985) determined a whole-rock $\mathrm{K}-\mathrm{Ar}$ age of $520 \pm 10 \mathrm{Ma}$ from one sample, and a $\mathrm{K}-\mathrm{Ar}$ (muscovite) age of $484 \pm 10 \mathrm{Ma}$ and a $\mathrm{Rb}-\mathrm{Sr}$ (muscovite) age of $507 \pm 5 \mathrm{Ma}$, from another sample, both localities being within $5 \mathrm{~km}$ of the Highland Boundary Fault. As with a whole-rock K-Ar age of $489 \pm 10$ Ma from $0.5 \mathrm{~km}$ north of the Fault along a similar traverse in Angus, these ages could be affected by the presence of old detrital muscovite grains which have not been outgassed during the regional metamorphism. However, four $\mathrm{Rb}-\mathrm{Sr}$ (muscovite) ages of 481-515 Ma from high-grade schists from the Tarfside culmination at the northern end of the Angus traverse cannot be explained in this way, and are not consistent with the hypothesis presented herein. The geological interpretation of several $\mathrm{Rb}-\mathrm{Sr}$ ages $>470 \mathrm{Ma}$ old on micas from the Dalradian Southern Highland Group in NE Scotland was the subject of a discussion between Evans \& Soper (1997) and Dempster et al. (1997).

As there is no compelling reason to consider that the rocks at Callander from the Dalradian to the top of the Keltie Water Grit Formation are not in their original stratigraphical sequence, then this formation should be logically be included within the Dalradian Southern Highland Group. The only remaining problem is that this would leave some $70 \mathrm{Ma}$ available for the deposition of a $>4 \mathrm{~km}$ thick sequence of turbidite facies grits, sandstones, and shales (Gibbons \& Harris 1994), above the Loch Tay Limestone, and suggests that an intraformational break may be present somewhere in the sequence. However, in deformed rocks with incomplete exposure, and lacking fossils, as at Callander, such a break would be difficult, if not impossible, to detect.
In conclusion, as all of these rocks can be shown to have shared the same structural history (Harris 1962; Tanner 1995), then the Grampian orogeny where it affects the Southern Highland Group, is of post-lower Cambrian age (i.e. post$509 \mathrm{Ma}$ ). The Tay Nappe deformations (regional D1 \& D2), and a possible earlier episode of deformation (Harris et al. 1998; Tanner 1998) are therefore of post-Cambrian age.

We are grateful to S. Sutherland for examining the limestone samples for chitinozoa; B. E. Leake for advice and assistance with the Niggli plots; S. P. Kelley for comments on the $\mathrm{Ar}-\mathrm{Ar}$ results; D. J. Fettes, G. Rogers, and especially T. Dempster, for their helpful comments. J. Gallacher is thanked for carrying out the XRF analyses, and R. McDonald for assistance with the microprobe work. This project was funded by NERC Grants GR9/1534 and IP/442/0395.

\section{References}

Anderson, J.G.C. 1947. The geology of the Highland Border: Stonehaven to Arran. Transactions of the Royal Society of Edinburgh, 61, 479-515.

Bhatia, M.R. \& Crook, K.A.W. 1986. Trace element characteristics of graywackes and tectonic setting discrimination of sedimentary basins. Contributions to Mineralogy and Petrology, 92, 181-193.

BLUCK, B.J. 1990. Terrane provenance and amalgamation: examples from the Caledonides. Philosophical Transactions of the Royal Society, London, 331, 599-609.

- Gibbons, W. \& Ingham, J.K. 1992. Terranes. In: Cope, J.C.W., Ingham, J.K. \& Rawson, P.F. (eds) Atlas of Palaeogeography and Lithofacies. Geological Society, London, Memoirs, 13, 1-3.

Brasier, M.D., Ingham, J.K. \& Rushton, A.W.A. 1992. Cambrian. In: Cope, J.C.W., Ingham, J.K. \& Rawson, P.F. (eds) Atlas of Palaeogeography and Lithofacies. Geological Society, London, Memoirs, 13, 13-18.

Clough, C.T. 1896. Unpublished field notes, available for inspection at the BGS, Edinburgh.

Conway Morris, S. \& Rushton, A.W.A. 1988. Precambrian to Tremadoc biotas in the Caledonides. In: Harris, A.L. \& FetTes, D.J. (eds) The Caledonian-Appalachian Orogen. Geological Society, London, Special Publications, 38, 93-109.

Copeland, P. \& Harrison, T.M. 1990. Episodic rapid uplift in the Himalaya revealed by ${ }^{40} \mathrm{Ar} /{ }^{39} \mathrm{Ar}$ analysis of detrital K-feldspar and muscovite, Bengal fan. Geology, 18, 354-357.

Cowie, J.W., Rushton, A.W.A. \& Stubblefield, C.J. 1972. A correlation of Cambrian rocks in the British Isles. Geological Society, London, Special Reports, 2.

Davidek, K., Landing, E., Bowring, S.A., Westrop, S.R., Rushton, A.W.A., Fortey, R.A. \& Adrain, J. 1998. New Uppermost Cambrian U-Pb date from Avalonian Wales and the age of the Cambrian-Ordovician boundary. Geological Magazine, 135, 303-309.

DempSter, T.J. 1985. Uplift patterns and orogenic evolution in the Scottish Dalradian. Journal of the Geological Society, London, 142, 111-128.

\& BLUCK, B.J. 1989. The age and origin of boulders in the Highland Border Complex: constraints on terrane movements. Journal of the Geological Society, London, 146, 377-379.

- Hudson, N.F.C. \& Rogers, G. 1995. Metamorphism and cooling of the NE Dalradian. Journal of the Geological Society, London, 152, 383-390.

_ _ \& _ 1997. Discussion of Metamorphism and cooling of the NE Dalradian; reply. Journal of the Geological Society, London, 154, 358-360.

Evans, J.A. \& Soper, N.J. 1997. Discussion on metamorphism and cooling of the NE Dalradian, and U-Pb and Rb-Sr geochronology of magmatism and metamorphism in the Dalradian of Connemara, western Ireland. Journal of the Geological Society, London, 154, 357-358.

Fitches, W.R., Pearce, N.J.G., Evans, J.A. \& Muir, R.J. 1996. Provenance of late Proterozoic Dalradian tillite clasts, Inner Hebrides, Scotland. In: Brewer, T.S. (ed.) Precambrian Crustal Evolution in the North Atlantic Region. Geological Society, London, Special Publications, 112, 367-377.

GeikiE, A. 1897. Annual Report of the Geological Survey for 1896, 28.

Gibbons, W. \& Harris, A.L. (eds) 1994. A revised correlation of Precambrian rocks in the British Isles. Geological Society, London, Special Reports, 22.

Halliday, A.N., Graham, C.M., Aftalion, M. \& Dymoke, P. 1989. The depositional age of the Dalradian Supergroup: $\mathrm{U}-\mathrm{Pb}$ and $\mathrm{Sm}-\mathrm{Nd}$ isotopic studies of the Tayvallich Volcanics, Scotland. Journal of the Geological Society, London, 146, 3-6. 
HARPER, C.T. 1967. The geological interpretation of potassium-argon ages of metamorphic rocks from the Scottish Caledonides. Scottish Journal of Geology, 3, 46-66.

HARris, A.L. 1962. Dalradian geology of the Highland Border near Callander. Bulletin of the Geological Survey of Great Britain, 19, 1-15.

— 1969. The relationships of the Leny Limestone to the Dalradian. Scottish Journal of Geology, 5, 187-190.

1970. Dalradian and supposed Arenig rocks. In: Francis, E.H. ET AL. (eds) The Geology of Stirling District (Explanation of One-Inch Geological Sheet 39). Institute of Geological Sciences, London, 7-10.

— \& FETTES, D.J. 1972. Stratigraphy and structure of Upper Dalradian rocks at the Highland Border. Scottish Journal of Geology, 8, 253-264.

, — \& SOPER, N.J. 1998. Age of the Grampian event: a Discussion of "New evidence that the Lower Cambrian Leny Limestone at Callander, Perthshire, belongs to the Dalradian Supergroup, and a reassessment of the 'exotic' status of the Highland Border Complex". Geological Magazine, 135, 575.

Jehu, T.J. \& Campbell, R. 1917. The Highland Border rocks of the Aberfoyle district. Transactions of the Royal Society of Edinburgh, 52, 175-212.

JiAnG, W. \& Peacor, D.R. 1994. Formation of corrensite, chlorite and chlorite-mica stacks by replacement of detrital biotite in low-grade pelitic rocks. Journal of Metamorphic Geology, 12, 867-884.

Kelley, S.P. \& BluCK, B.J. 1992. Laser ${ }^{40} \mathrm{Ar} /{ }^{39} \mathrm{Ar}$ ages for individual detrital muscovites in the Southern Uplands of Scotland, U.K. Chemical Geology, 101, 143-156.

LEAKE, B.E. 1996. Geochemically unravelling the sedimentary components of Archaen metasediments from Western Australia. Journal of the Geological Society, London, 153, 637-651.

McDougall, I. \& Harrison, T.M. 1988. Geochronology and thermochronology by the ${ }^{40} \mathrm{Ar}^{39} \mathrm{Ar}$ method. University Press, New York.

NicoL, J. 1863. On the geological structure of the southern Grampians. Quarterly Journal of the Geological Society of London, 19, 180-209.

Pidgeon, R.T. \& Compston, W. 1992. A shrimp ion microprobe study of inherited and magmatic zircons from four Scottish Caledonian granites. Transactions of the Royal Society of Edinburgh: Earth Sciences, 83, 473-483.

Pringle, J. 1939. The discovery of Cambrian trilobites in the Highland Border rocks near Callander, Perthshire. Report of the British Association for the Advancement of Science, 1, 252.

ReAD, H.H. 1961. Aspects of Caledonian magmatism in Britain. Liverpool and Manchester Geological Journal, 2, 653-683.
Rogers, G., Dempster, T.J., Bluck, B.J. \& Tanner, P.W.G. 1989. A high precision $\mathrm{U}-\mathrm{Pb}$ age for the Ben Vuirich granite: implications for the evolution of the Scottish Dalradian Supergroup. Journal of the Geological Society, London, 146, 789-798.

Rushton, A.W.A., Owen, A.W., Owens, R.M. \& Prigmore, J.K. In press. British Cambrian and Ordovician stratigraphy. Geological Conservation Review Series No. 19, Joint Nature Conservation Committee, Peterborough.

SpeER, J.A. 1984. Micas in igneous rocks. In: BAILEY, S.W. (ed.) Micas. Mineralogical Society of America, Reviews in Mineralogy, 13, 299-356.

Stone, M. 1957. The Aberfoyle Anticline, Callander, Perthshire. Geological Magazine, 94, 265-76.

TANNER, P.W.G. 1995. New evidence that the Lower Cambrian Leny Limestone at Callander, Perthshire, belongs to the Dalradian Supergroup, and a reassessment of the 'exotic' status of the Highland Border Complex. Geological Magazine, 132, 473-483.

— 1996. Significance of the early fabric in the contact metamorphic aureole of the $590 \mathrm{Ma}$ Ben Vuirich Granite, Perthshire, Scotland. Geological Magazine, 133, 683-695.

— 1998. Age of the Grampian event: Reply to a Discussion of 'New evidence that the Lower Cambrian Leny Limestone at Callander, Perthshire, belongs to the Dalradian Supergroup, and a reassessment of the "exotic" status of the Highland Border Complex'. Geological Magazine, 135, 575-579.

— \& LesLIE, A.G. 1994. A pre-D2 age for the 590 Ma Ben Vuirich Granite in the Dalradian of Scotland. Journal of the Geological Society, London, 151, 209-212.

Thомаs, C.W. 1989. Application of geochemistry to the stratigraphic correlation of Appin and Argyll Group carbonate rocks from the Dalradian of northeast Scotland. Journal of the Geological Society, London, 146, 631-647.

Turner, S.P., Kelley, S.P., VandenBerg, A.H.M., Foden, J.D., Sandiford, M. \& FLöttmanN, T. 1996. Source of the Lachlan fold belt flysch linked to convective removal of the lithospheric mantle and rapid exhumation of the Delamerian-Ross fold belt. Geology, 24, 941-944.

van de Kamp, P.C. \& Leake, B.E. 1985. Petrography and geochemistry of feldspathic and mafic sediments of the northeastern Pacific margin. Transactions of the Royal Society of Edinburgh: Earth Sciences, 76, 411-449. 